\title{
Intestinal growth and function of broiler chicks fed sorghum based diets differing in condensed tannin levels
}

\author{
B. Nyamambi ${ }^{1 \#}$, L.R. Ndlovu ${ }^{1,2}$, Y.S. Naik ${ }^{1,2}$ and N.D. Kock ${ }^{1,3}$ \\ ${ }^{1}$ Departments of Animal Science, Biochemistry and Veterinary Paraclinical Studies, University of Zimbabwe, \\ Box MP 167, Mount Pleasant, Harare, Zimbabwe \\ ${ }^{2}$ Department of Environmental Science and Health, National University of Science and Technology, Bulawayo, Zimbabwe \\ ${ }^{3}$ Department of Pathology-Comparative Medicine, Medical Centre Boulevard, School of Medicine, Wake Forest \\ University, Winston- Salem, North Carolina, 27157, U.S.A
}

\begin{abstract}
The effect of feeding sorghum condensed tannins on intestinal growth, function and histology was investigated in an 8-week broiler growth trial. Four sorghum varieties of different proanthocyanidins (PA) content; DC75 (DC - $2.48 \mathrm{~A}_{550 \mathrm{~nm}} / \mathrm{g}$ DM) Chirimaugute $\left(\mathrm{CH}-1.68 \mathrm{~A}_{550 \mathrm{~nm}} / \mathrm{g} \mathrm{DM}\right)$, Brown Tsweta (BT - 0.2 $\mathrm{A}_{550 \mathrm{~nm}} / \mathrm{g} \mathrm{DM}$ ), SV2 (SV - $0.07 \mathrm{~A}_{550 \mathrm{~nm}} / \mathrm{g} \mathrm{DM}$ ) and maize (MA) were used to formulate four diets each with one sorghum variety (CH, BT and SV) and maize included as the principal energy source. DC75 was used to replace 50 (DC50) and 100\% (DC100) w/w maize to form the other two treatment diets. Relative weights of the small intestine differed significantly at 21 days of age. However, the decrease in weight did not correspond to the increase in PA level in a linear manner. Villus height and crypt depth were reduced at seven (7\%) and 14 days (15\%) in broilers fed DC and CH diets and thereafter was similar to MA and SV fed birds. The liver total and esterified cholesterol was reduced in DC100, DC50 and CH fed birds. Grain sorghum contains other phytochemicals such as policosanols and sterols besides PA which compound the observations in the liver. The effect of age on the severity of local liver lesions was not significant. The DC100 fed chicks showed mild crypt necrosis and/or sub-acute crypt distortion. There was a significant increase in the goblet cell number $/ \mathrm{mm}^{2}$ measured in the jejunum of chicks fed CH, DC50 and DC100 diets. Sucrase but not maltase activity was significantly reduced with increased PA content in the 7-, 14- and 21-days age groups. From the results it appears that the dietary PA levels are not limiting factors in the development of the gastrointestinal tract of broiler chicks.
\end{abstract}

Keywords: Sorghum, condensed tannins, intestinal adaptation, villus height, goblet cell density

\#Corresponding author. E-mail: bethule@mweb.co.zw

\section{Introduction}

Tannins are present in a wide range of plant species used in poultry feeding, including sorghum, peas and cottonseed (Farrell et al., 1999). The inclusion of sorghum grain high in condensed tannins (syn. proanthocyanidins, PA) in poultry feeds has been shown to have negative effects on live performance of broiler chicks (Armstrong et al., 1974; Sell et al., 1985; Rubio et al., 1990). These negative effects have been shown such as reduced body weight gain and feed efficiency (Douglas et al., 1990; Elkin et al., 1990) and has been attributed to the ability of tannins to bind, coagulate and precipitate protein (Butler et al., 1986) including digestive enzymes through hydrophobic and other interactions (Hagerman et al., 1981), thereby reducing digestion and absorption of nutrients (Farrell et al., 1999).

The tannin chemical structure, in addition to protein binding capacity, determines the rate and extent of intestinal absorption and the nature of the metabolites. The PAs that predominate in sorghums are reported not to be easily absorbed into the body because of their large molecular weight (Santos-Buelga et al., 2000). Therefore, their site of activity could only be localized in the gastrointestinal tract (Jimenez-Ramsey et al., 1994). Evidence showing the absorption of PAs or their related phenolics is still scarce. Few reports have documented the effects of dietary PA or related phenolics on the localised intestinal growth and function in broiler chickens and the contribution to changes in performance.

In a study done with chicks and rats given diets high in freeze-dried tannins extracted from faba beans (Vicia faba), Ortiz et al. (1994) found histological lesions in the ileum and liver suggesting a loss in absorptive capacity. In the liver degeneration of hepatocytes was observed. They attributed this to the high tannin content of 
the diet, which was estimated at $16 \mathrm{~g}$ dried tannin/kg DM. However, the levels used in their experiment were not set at practical dietary levels for broiler feeding. It is expected that the concentration of dietary sorghum PA will be much less than the above referred levels and consequently the effects may be milder or negligible. Results obtained by Sell et al. (1985) using high and low tannin sorghum for rats and laying hens revealed milder negative effects. Examination of the distal digestive tract under light microscope showed normal cells. The only effect appeared to be a mild reduction in crypt depth and intestinal wall thickness and an increase in mucus secretion in the intestinal tract. According to Sell et al. (1985) this could reduce the absorptive capacity of gut.

The integral function of the epithelial layer and release of brush border membrane (BBM) enzymes are fundamental to the digestion and absorption of nutrients from the intestinal lumen. The epithelium is covered by a layer of mucus composed of mucin glycoproteins that are synthesised by goblet cells. The mucous layer acts as a layer of protection, lubrication and transport between luminal contents and epithelial cells (Uni et al., 1998). Changes in the properties of this barrier could affect the absorption of both dietary and endogenous macromolecules and ions. Butler (1992) has suggested that high levels of tannins can cause gastroenteritis and congestion of the intestinal wall in rats. A deficiency in sucrase activity due to tannin ingestion has been found to reduce the absorption efficiency of BBM vesicles (Welsch et al., 1989). In a study to assess the effect of dietary phenolic compounds on glucose uptake in intestinal BBM vesicles of rats, morphological changes were found to be accompanied by a severe impairment of the brush border enzyme, sucrase, to about one third of normal enzyme activity (Welsch et al., 1989). Ahmed et al. (1991) deduced that this might have been the result of either direct complex formation between enzymes and tannins or through secondary effects, which led to diminished activity such as changing the gut wall morphology.

Apart from the study done by Sell et al. (1985), few investigations are known to the authors that, qualitatively and quantitatively, show the extent of the effects of ingesting dietary sorghum PA on histology of the digestive system of chicks. The present study was designed to investigate the effects of sorghum condensed tannins, PA, on the growth, function and morphology of the digestive and absorptive system in broiler chicks and relate it to chick growth.

\section{Materials and Methods}

Four sorghum varieties of different PA content; DC75 (DC, 2.48 A $550 \mathrm{~nm} / \mathrm{g}$ DM) Chirimaugute (CH, 1.68 $\mathrm{A}_{550 \mathrm{~nm}} / \mathrm{g}$ DM), B. Tsweta (BT, 0.20. A $550 \mathrm{~nm} / \mathrm{g}$ DM), SV2 (SV, $0.07 \mathrm{~A}_{550 \mathrm{~nm}} / \mathrm{g}$ DM) and maize (MA) were selected for the study. DC75 was obtained from a local poultry feed manufacturer in Zimbabwe whilst other varieties were obtained from Matopos Research Station, located in southwest of Zimbabwe with a mean diurnal temperature of $27^{\circ} \mathrm{C}$ and an annual rainfall of $600 \mathrm{~mm}$. Proximate composition and amino acid content were determined (AOAC, 1990) and used to formulate starter diets, giving $230 \mathrm{~g} \mathrm{CP} / \mathrm{kg}$ and $12.6 \mathrm{MJ} \mathrm{ME} / \mathrm{kg}$, and grower diets, giving 190-200 g CP/kg and $13 \mathrm{MJ} \mathrm{ME} / \mathrm{kg}$. Four diets each with one sorghum variety (CH, BT and SV) and maize included as the principal energy source were formulated. In addition, two more diets with DC replacing 50\% (DC50) and 100\% (DC100) w/w maize were formulated. Diet composition and analysis are shown in Table 1.

Three hundred and sixty day-old male Cobb broiler chicks, obtained from a commercial hatchery, were weighed and separated into experimental units in a completely randomised design. Six replicates of 10 chicks each with statistically similar mean live weight of $30.6 \pm 0.56 \mathrm{~g}$ were assigned to each of the six treatment groups. Chicks were fed on the starter diet from 1 to 21 days followed by grower diet from 22 to 56 days. Water and feed were given to the chicks ad libitum. Weekly measurements of body weight (LW) and feed intake (FI) for each replicate of the treatments were taken.

At days 7, 14, 21, 42 and 56 two chicks from each replicate were killed after starving them for 12 hours to limit intestinal throughput. To ensure clean histology samples, the liver and intestinal samples were removed with sterile surgical tools in a cool environment. Livers were removed and weighed. The liver was dissected to remove a $2 \mathrm{~cm}$ diameter sample, which was immediately washed with $1 \% \mathrm{NaCl}$ and stored in $10 \%$ neutral buffered formalin, and the rest was kept in liquid nitrogen. From samples obtained on days 7, 14 and 21, the whole length of the small intestine was removed, washed and weighed. From the small intestine of one bird per replicate, a length of $3 \mathrm{~cm}$ jejunum was cut midway between the end of the duodenum where bile duct and pancreatic ducts meet and the embryonic sac junction, washed with $1 \% \mathrm{NaCl}$ to remove intestinal contents, weighed and then fixated with $10 \%$ neutral buffered formal saline. To eliminate as much variation as possible, two people were trained to wash and empty the intestinal contents.

Two cross-sections of the preserved small intestine and liver samples were processed for 24 hours in a 
tissue processor with ethanol as dehydrant and samples embedded in paraffin wax. Five $\mu \mathrm{m}$ sections were made from the tissue and were stained with haematoxylin-eosin. Samples were viewed under a light microscope (Leitz Dialux 20, Leitz, Wetzlar, Germany). Morphometric variables measured were villus height (tip of the villus to the villus crypt junction) and crypt depth (depth of area between adjacent villi). The height of 10 villi was measured at a magnification of x 200 using an eyepiece with a ruled grid, and mean value was calculated. The density of the goblet cells was calculated as the number of cells per $\mathrm{mm}^{2}$.

Table 1 Composition of experimental starter (1-21 days) and grower (22-56 days) diets

\begin{tabular}{|c|c|c|c|c|c|c|}
\hline & \multicolumn{6}{|c|}{ Treatments $^{\mathrm{b}}$} \\
\hline & MA & SV & BT & $\mathrm{CH}$ & DC100 & $\mathrm{DC} 50^{\mathrm{c}}$ \\
\hline \multicolumn{7}{|l|}{ Starter diets } \\
\hline \multicolumn{7}{|l|}{ Ingredients (g/kg) } \\
\hline Maize & 534 & - & - & - & - & 284 \\
\hline Sorghum & - & 570 & 570 & 573 & 570 & 283 \\
\hline Soyabean meal & 390 & 357 & 359 & 355 & 357 & 363 \\
\hline Meat and bone meal & 43 & 40 & 39 & 39 & 40 & 38 \\
\hline Vitamin mineral premix ${ }^{\mathrm{d}}$ & 33 & 33 & 33 & 33 & 33 & 33 \\
\hline \multicolumn{7}{|l|}{ Composition (g/kg) } \\
\hline $\mathrm{ME}(\mathrm{MJ} / \mathrm{kg})$ & 12.5 & 12.8 & 12.38 & 12.54 & 12.16 & 12.42 \\
\hline Crude protein (g/kg DM) & 22.4 & 22.1 & 23.0 & 22.8 & 22.5 & 22.8 \\
\hline Methionine & 4.02 & 4.01 & 3.98 & 4.02 & 4.00 & 4.02 \\
\hline Lysine & 13.16 & 13.15 & 13.18 & 13.08 & 13.08 & 13.02 \\
\hline \multicolumn{7}{|l|}{ Grower diets } \\
\hline \multicolumn{7}{|l|}{ Ingredients (g/kg) } \\
\hline Maize & 677 & - & - & - & - & 320 \\
\hline Sorghum & - & 698 & 714 & 690 & 695 & 360 \\
\hline Soyabean meal & 264 & 245 & 230 & 252 & 249 & 261 \\
\hline Meat and bone meal & 29 & 27 & 26 & 28 & 27 & 29 \\
\hline Vitamin and mineral premix ${ }^{\mathrm{d}}$ & 30 & 30 & 30 & 30 & 30 & 30 \\
\hline \multicolumn{7}{|l|}{ Composition (g/kg) } \\
\hline $\mathrm{ME}(\mathrm{MJ} / \mathrm{kg})$ & 12.4 & 12.4 & 12.1 & 12.9 & 12.38 & 12.7 \\
\hline Crude protein & 19 & 18.3 & 18.0 & 18.5 & 18.4 & 18.95 \\
\hline Methionine & 3.5 & 3.9 & 3.9 & 3.4 & 3.1 & 3.2 \\
\hline Lysine & 10.0 & 9.2 & 8.1 & 9.3 & 8.2 & 9.4 \\
\hline PA level $\left(A_{550 \mathrm{~nm}} / \mathrm{g} D M\right)^{\mathrm{a}}$ & 0 & 0.07 & 0.2 & 1.68 & 2.48 & 2.48 \\
\hline
\end{tabular}

\footnotetext{
${ }^{a}$ PA levels measured using the Butanol-HCl method as described by Porter et al. (1986)

b Treatments: $\mathrm{MA}=$ Maize; SV = SV2; BT = Brown Tsweta $\mathrm{CH}=$ Chirimaugute; $\mathrm{DC}=$ DC 75; DC100 = $100 \mathrm{w} / \mathrm{w}$ DC75 grain diet

${ }^{\mathrm{c}}$ DC50 = Grain was mixed 50/50 w/w DC75 with maize on an air-dry basis

${ }^{\mathrm{d}}$ Broiler vitamin and mineral premix contained (/kg): $11.7 \mathrm{~g}$ dicalcium phosphate; $4.5 \mathrm{~g}$ salt; 6500 IU vitamin A; 2000 IU vitamin $\mathrm{D}_{3}, 25 \mathrm{mg}$ vitamin $\mathrm{E} ; 5 \mathrm{mg}$ vitamin $\mathrm{B}_{2} ; 0.01 \mathrm{mg}$ vitamin $\mathrm{B}_{12} ; 30 \mathrm{mg}$ niacin 30; $0.2 \mathrm{mg}$ folic acid; $0.2 \mathrm{mg}$ biotin; $500 \mathrm{mg}$ choline; $3 \mathrm{mg}$ dicalcium phosphate vitamin $\mathrm{K}_{3} ; 15 \mathrm{mg}$ pantothenic acid; and vitamin $\mathrm{B}_{6}$, ethoxyquin, manganese oxide, potassium iodide, cobalt sulphate, zinc oxide, copper oxide, ferrocarbonate and calcium carbonate.
}

A $10 \mathrm{~cm}$ length of jejunum was excised from one of each treatment replicates, rinsed with ice cold water and $154 \mathrm{mM} \mathrm{NaCl}$ and cut open on an ice-cooled surface. The contents of the jejunum were scraped off gently into the homogenisation buffer in a pre-weighed specimen tube and chilled with crushed ice for 30 seconds before homogenisation. The samples were homogenised in a Potter-Elvehjem tissue homogeniser for 1-2 min and immediately stored at $-80^{\circ} \mathrm{C}$ until further analysis. 
The specific activities of maltase (E.C. 3.2.1.20) and sucrase (E.C. 3.2.1.26) were measured using methods described by Dahlqvist (1964). Chemicals were obtained from Sigma Aldrich Company, South Africa. Protein content was determined using the Lowry et al. (1951) method. Specific activity was determined spectrophotometrically as the quantity of product $(\mu \mathrm{g})$ liberated $/ \mathrm{min} / \mathrm{mg}$ of protein at $37^{\circ} \mathrm{C}$.

Liver lipid was determined after extraction with chloroform: methanol (2:1) according to Folch et al. (1957) and liver fatty acid composition was determined by gas chromatography using three samples from each treatment. Total cholesterol, free cholesterol, triglycerides and phospholipids were determined using enzymes (Carr et al., 1993) and esterified cholesterol calculated as the difference between total and free cholesterol. Treatment differences were identified by analysis of variance using the general linear model procedure of the Statistical Analysis System Version 6 (SAS, 2000), using diet treatment (PA level) as the independent factor. Comparison of treatment means was done by the Duncan's multiple range test and differences were considered significant at a level of $\mathrm{P}<0.05$. The association between tannin level and morphological measurements and enzyme activity was investigated using the Pearson correlation procedure.

\section{Results and Discussion}

The effect of PA level on performance assessed from 0 to 56 days is summarised in Table 2. The DC100 fed birds had lower $(\mathrm{P}<0.001)$ live weights than the SV, BT, CH and DC50 but not the MA fed birds. DC50 fed birds performed similarly to SV fed birds throughout the trial. The average daily gain (ADG) of DC100 and $\mathrm{CH}$ fed birds was lower $(\mathrm{P}<0.001)$ in the period 0-7 days and 0-21 days. In the grower period, days 22 to 42 , $\mathrm{CH}$ fed birds gained similarly to MA, BT and DC50 fed birds, but the DC100 fed remained lower $(\mathrm{P}<0.001)$. There were no significant differences in ADG at days 42 and 56. In contrast, average daily feed intake (ADFI) did not differ across treatments except in the period 0 to 7 days $(\mathrm{P}<0.001)$ (DC100 12.5 g/bird/day, CH 14.2 g/bird/day, BT 14.2 g/bird/day, DC50 15.2 g/bird/day, MA 14.9 g/bird/day and SV 16.7 g/bird/day). Feed utilization (g gain/kg feed eaten) was unaffected by treatment throughout the trial except in the period 21 to 42 days, where DC100 fed birds became less efficient $(\mathrm{P}<0.01)$. Mortalities recorded for the entire study period were unrelated to treatment.

Figure 1 represents the relative weights (g/100 g LW) of the liver and small intestine of broilers fed the treatment diets. There were no differences in the liver relative weights, apart from the $56 \mathrm{~d}$ measurement for DC100 and MA (1.93 vs. $2.43 \mathrm{~g} / 100 \mathrm{~g} \mathrm{LW)} \mathrm{(Figure} \mathrm{1(a)).} \mathrm{Generally} \mathrm{dietary} \mathrm{tannins} \mathrm{do} \mathrm{not} \mathrm{seem} \mathrm{to} \mathrm{influence}$ liver weights in chicks (Ahmed et al., 1991; Nyachoti et al., 1996) and the results of the present study support this conclusion. Small intestinal relative weights differed at 7 and 21 days $(\mathrm{P}<0.001)$ (Figure $1(\mathrm{~b})$ ). The decrease in small intestinal weight did not correspond to the increase in PA level in a linear manner ((BT fed chicks were lower (5.7 g/100 g LW) than CH or DC100 (6.9 and 7.01 g/100 g LW, respectively) at seven days, similar at 14 days, but higher at 21 days (3.4 - BT vs. $3.1 \mathrm{DC} 100 \mathrm{~g} / 100 \mathrm{~g} \mathrm{LW},(\mathrm{P}>0.05))$. Thus, there was no real evidence to conclude an effect of PA ingestion on the size or growth of the small intestine. The grains in the present experiment were ground to pass through a similar coarse mesh, thus eliminating any variation in grain size. It is possible that other factors may influence the small intestinal size. Studies done on post hatch gross intestinal development indicated that the small intestine develops faster than the whole body mass and even in the absence of exogenous feed and nutrients, the small intestines do increase in size and functional capacity. This increase occurs in the first 6-10 days of a chick's life (Noy et al., 2001).

Duodenal villus height $(\mu \mathrm{m})$ and crypt depth $(\mu \mathrm{m})$ were slightly reduced $(\mathrm{P}<0.001)$ with increasing PA levels (Table 3). Morphology of the small intestinal sections of MA and SV samples were considered normal. The 7 and $14 \mathrm{~d}$ villus height of chicks fed DC100, CH and BT diets were lower $(\mathrm{P}<0.001)$ than villus height of chicks raised on the MA, SV and DC50 diets, suggesting a reduced ability to utilise nutrients in the intestine. These differences were not observed in samples from 42 and 56 days. Villi in DC50 fed birds were consistently similar in size to those of non-PA diets - MA and SV fed birds. Villus growth in the young chick is stimulated by the presence of feed and the availability of nutrients will markedly increase the villus height (Moran, 1982). Chicks fed DC100 also had sub-acute crypt distortion, and irregular crypt morphology was observed in CH fed birds at 21 and 42 days. There is a possibility that these samples may have undergone mild hyperplasia. The findings of Sell et al. (1985) who studied the effects of feeding high tannin and low tannin sorghum on the morphology of the duodenum, ileum, caecum and colon of rats, chicks and laying hens, revealed 
Table 2 Summary of average daily gain (ADG), daily feed intake (ADFI) and feed efficiency (FE) of broilers fed sorghum diets varying in PA content

\begin{tabular}{|c|c|c|c|c|c|c|c|c|}
\hline & \multicolumn{6}{|c|}{ Treatments ${ }^{x}$} & \multirow{2}{*}{ m.s.d. } & \multirow{2}{*}{$\mathrm{P}$ value } \\
\hline & MA & SV & $\mathrm{BT}$ & $\mathrm{CH}$ & $\mathrm{DC} 50^{x}$ & DC100 ${ }^{x}$ & & \\
\hline \multicolumn{9}{|l|}{ Live weight (g) } \\
\hline 42 days & $1419^{\mathrm{bc}}$ & $1550^{\mathrm{a}}$ & $1487^{\mathrm{ab}}$ & $1457^{\mathrm{b}}$ & $1474^{\mathrm{ab}}$ & $1373^{c}$ & 57.48 & 0.001 \\
\hline 56 days & $2463^{b}$ & $2561^{\mathrm{a}}$ & $2475^{a b}$ & $2443^{b}$ & $2475^{a b}$ & $2321^{\mathrm{c}}$ & 96.69 & 0.001 \\
\hline \multicolumn{9}{|l|}{ ADG (g/bird/day) } \\
\hline 0-7 days & $10.4^{\mathrm{a}}$ & $10.8^{\mathrm{a}}$ & $9.6^{\mathrm{b}}$ & $9.5^{b}$ & $10.5^{\mathrm{a}}$ & $8.3^{\mathrm{c}}$ & 0.48 & 0.001 \\
\hline 0 -21 days & $15.3^{\mathrm{a}}$ & $16.0^{\mathrm{a}}$ & $15.0^{\mathrm{ab}}$ & $15.1^{\mathrm{a}}$ & $15.1^{\mathrm{a}}$ & $13.6^{\mathrm{b}}$ & 1.49 & 0.025 \\
\hline 0-42 days & 34.8 & 35.9 & 34.4 & 33.7 & 34.1 & 31.7 & 1.37 & 0.001 \\
\hline 0-56 days & 43.3 & 45.0 & 43.4 & 42.9 & 43.5 & 40.7 & 1.73 & 0.001 \\
\hline 21-42 days & $50.4^{\mathrm{ab}}$ & $55.9^{\mathrm{a}}$ & $53.9^{\mathrm{ab}}$ & $52.3^{\mathrm{bc}}$ & $53.2^{b}$ & $49.9^{c}$ & 2.64 & 0.001 \\
\hline 42-56 days & 74.6 & 72.2 & 70.6 & 70.4 & 71.5 & 67.7 & 10.6 & 0.55 \\
\hline \multicolumn{9}{|l|}{ ADFI (g/bird/day) } \\
\hline 0-7 days & $14.9^{b}$ & $16.2^{\mathrm{a}}$ & $14.4^{\mathrm{b}}$ & $14.2^{b}$ & $15.2^{\mathrm{ab}}$ & $12.5^{b}$ & 1.06 & 0.001 \\
\hline 0 -21 days & 38.9 & 38.7 & 38.4 & 38.3 & 38.0 & 38.1 & 4.47 & 0.978 \\
\hline 21-42 days & 83.8 & 83.9 & 82.3 & 85.5 & 83.6 & 83.5 & 7.98 & 0.877 \\
\hline 42-56 days & 99.7 & 101.1 & 100.5 & 100.8 & 99.0 & 99.6 & 10.7 & 0.984 \\
\hline \multicolumn{9}{|l|}{ Feed efficiency ${ }^{y}$} \\
\hline 0-7 days & 0.69 & 0.67 & 0.67 & 0.67 & 0.69 & 0.67 & 0.093 & 0.861 \\
\hline $0-21$ days & 0.54 & 0.56 & 0.54 & 0.53 & 0.53 & 0.50 & 0.087 & 0.569 \\
\hline 21-42 days & $0.60^{\mathrm{b}}$ & $0.67^{\mathrm{a}}$ & $0.65^{\mathrm{ab}}$ & $0.61^{\mathrm{bc}}$ & $0.64^{\mathrm{abc}}$ & $0.59^{c}$ & 0.048 & 0.012 \\
\hline 42-56 days & 0.49 & 0.48 & 0.47 & 0.47 & 0.48 & 0.45 & 0.092 & 0.723 \\
\hline $\mathrm{PA}\left(\mathrm{A}_{550 \mathrm{~nm}} / \mathrm{g} \mathrm{DM}\right)$ & 0 & 0.07 & 0.20 & 1.68 & $1.24^{z}$ & 2.48 & & \\
\hline
\end{tabular}

${ }^{x}$ Treatments: MA = Maize; SV = SV2; BT = Brown Tsweta; CH= Chirimaugute; DC50 = 50/50 w/w maize/DC75; DC100 = 100 w/w DC75

${ }^{\mathrm{y}}$ Feed efficiency - g gain/kg feed intake

${ }^{z}$ PA - proanthocyanidin level, diluted by mixture and estimated to be at 50\% PA

m.s.d. - mean square difference

${ }^{a b c}$ Row means with different superscripts differ significantly $(\mathrm{P}<0.01)$ 
(a)

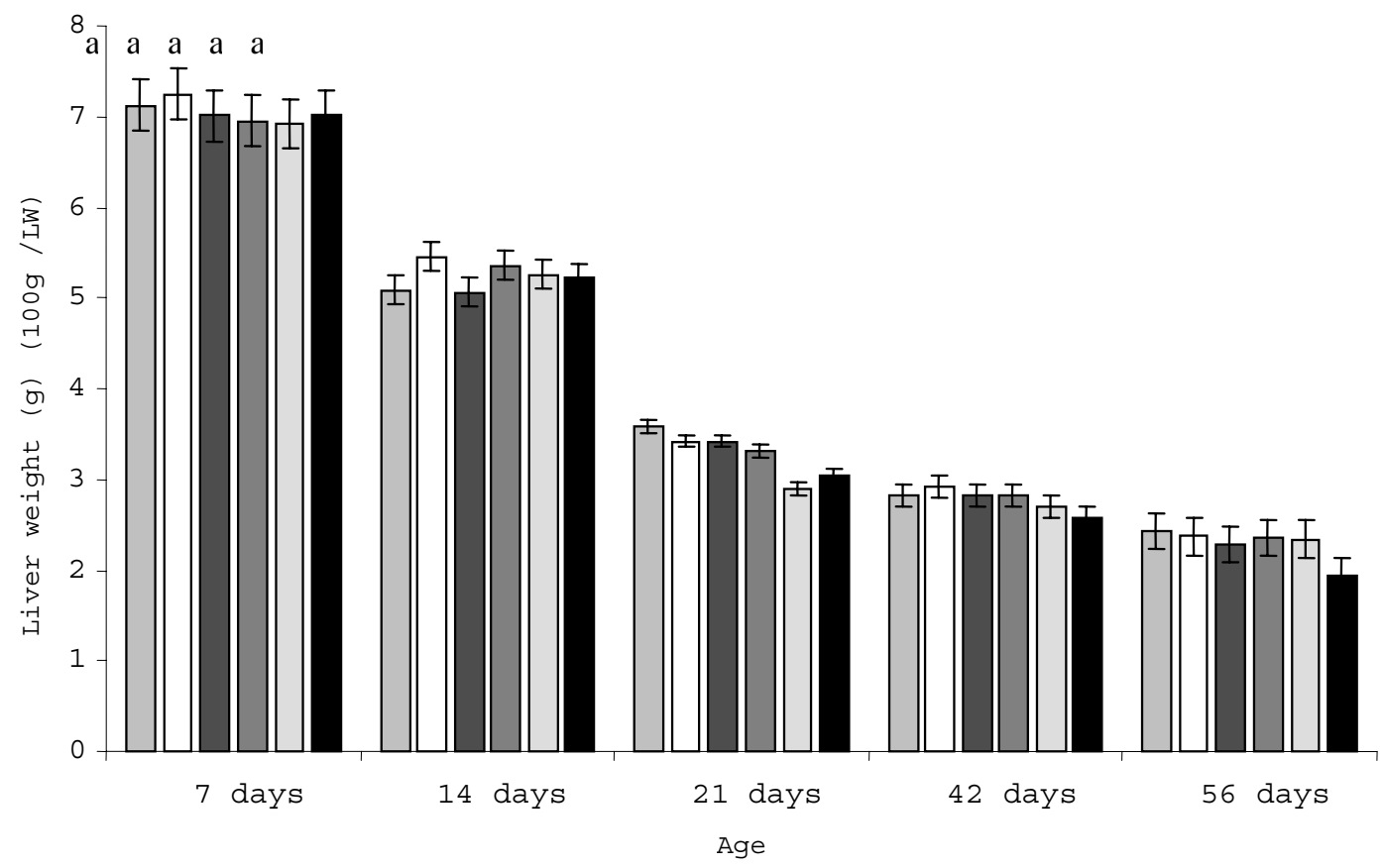

(b)

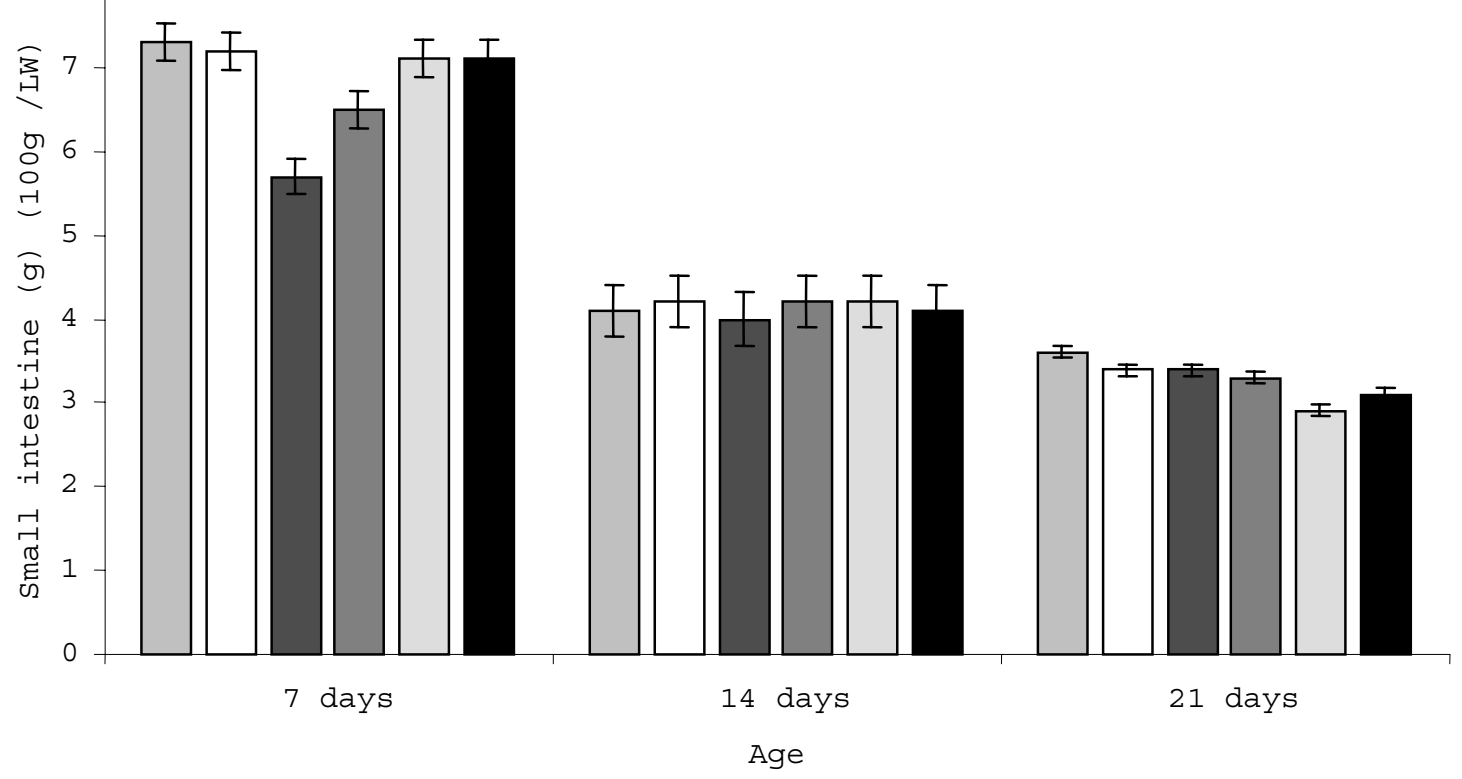

$\square \mathrm{MA} \quad \square \mathrm{SV} \quad \square \mathrm{BT} \quad \square \mathrm{CH} \quad \square \mathrm{DC} 50 \quad \square \mathrm{DC} 100$

Figure 1 Effect of sorghum proanthocyanidins (PA) levels on a) relative weight of liver measured at days 7, 14, 21, 42 and 56 and b) Relative weight of small intestine measured at days 7, 14 and 21 to live weight (LW). Values are means \pm s.e.m. a,b,c - Bars with different letters above represent means that differ significantly $(\mathrm{P}<0.01)$. 
Table 3 Morphometric measurements of the small intestine of broilers fed sorghum diets varying in PA level

\begin{tabular}{|c|c|c|c|c|c|c|c|c|}
\hline & \multicolumn{6}{|c|}{ Treatments $^{x}$} & \multirow{2}{*}{ m.s.d. ${ }^{y}$} & \multirow{2}{*}{$\mathrm{P}$ value } \\
\hline & MA & SV & BT & $\mathrm{CH}$ & DC50 & DC100 & & \\
\hline \multicolumn{9}{|l|}{ Villus height $(\mu \mathrm{m})$} \\
\hline 7 days & $610^{\mathrm{a}}$ & $603^{\mathrm{a}}$ & $587^{b}$ & $571^{\mathrm{c}}$ & $587^{\mathrm{b}}$ & $571^{\mathrm{c}}$ & 11.01 & 0.0004 \\
\hline 14 days & $711^{a b}$ & $726^{a}$ & $707^{\mathrm{a}}$ & $690^{\mathrm{c}}$ & $740^{\mathrm{a}}$ & $676^{\mathrm{b}}$ & 13.61 & 0.0004 \\
\hline 21 days & $810^{\mathrm{a}}$ & $816^{\mathrm{ab}}$ & $798^{\mathrm{ab}}$ & $799^{a b}$ & $832^{\mathrm{ab}}$ & $775^{b}$ & 30.73 & 0.03 \\
\hline 42 days & 1077 & 1099 & 1079 & 1079 & 1077 & 1056 & 81.63 & 0.76 \\
\hline 56 days & 1218 & 1231 & 1225 & 1218 & 1223 & 1178 & 99.78 & 0.69 \\
\hline \multicolumn{9}{|l|}{ Crypt depth $(\mu \mathrm{m})$} \\
\hline 7 days & $104^{\mathrm{a}}$ & $102^{\mathrm{a}}$ & $97^{\mathrm{b}}$ & $95^{b}$ & $97^{b}$ & $91^{\mathrm{c}}$ & 2.68 & 0.0004 \\
\hline 14 days & $123^{\mathrm{a}}$ & $119^{\mathrm{b}}$ & $118^{\mathrm{b}}$ & $114^{\mathrm{c}}$ & $114^{\mathrm{c}}$ & $113^{c}$ & 3.66 & 0.0028 \\
\hline 21 days & 149 & 150 & 149 & 149 & 154 & 144 & 8.31 & 0.15 \\
\hline 42 days & 173 & 171 & 169 & 169 & 177 & 164 & 9.54 & 0.09 \\
\hline 56 days & 192 & 188 & 190 & 188 & 200 & 188 & 17.96 & 0.42 \\
\hline $\mathrm{PA}\left(\mathrm{A}_{550} \mathrm{~nm} / \mathrm{g} \mathrm{DM}\right)$ & 0 & 0.07 & 0.20 & 1.68 & 2.48 & 2.48 & & \\
\hline
\end{tabular}

${ }^{x}$ Treatments : MA = Maize; SV = SV2; BT = Brown Tsweta CH = Chirimaugute; DC50 = 50/50 w/w maize/DC75; DC100 = 100 w/w DC75

${ }^{y}$ m.s.d - mean square difference

PA - proanthocyanidins

${ }^{a b c}$ Row means with different superscripts differ significantly $(\mathrm{P}<0.01)$ 
similar findings. The authors observed that although the intestinal sections were morphologically normal when examined under a light microscope, the only consistent effect appeared to be a slight reduction in the crypt depth and wall thickness of the duodenal tissue in animals fed the high tannin sorghum.

The proliferation of goblet cells in the jejunal area was studied in addition to villus height (Figure 2). There was a significant increase in the goblet cell density (number $/ \mathrm{mm}^{2}$ ) in the $\mathrm{CH}$, DC50 and DC100 fed birds at 21 and 42 days. SV fed birds had a 15\% higher goblet cell number than the MA fed birds and this increased to $30 \%$ in DC100 fed birds at 42 days. The intestinal mucous layer is a balance between mucin dynamics (goblet cells activity) and the continual erosion process of the mucous layer (Moran, 1982; Smirnov et al., 2004). Mucus is secreted by goblet cells throughout the gastrointestinal tract and forms a gel adherent to the mucosal surface (Langhout et al., 1999) and a proliferation of goblet cells could indicate an increase in the mucous layer and to offset the decrease in villus height seen in this study in an effort to normalise enzyme and absorptive capacity in the intestine. Mijavila et al. (1977) and Sell et al. (1985) observed mucus hypersecretion in rat epithelium.

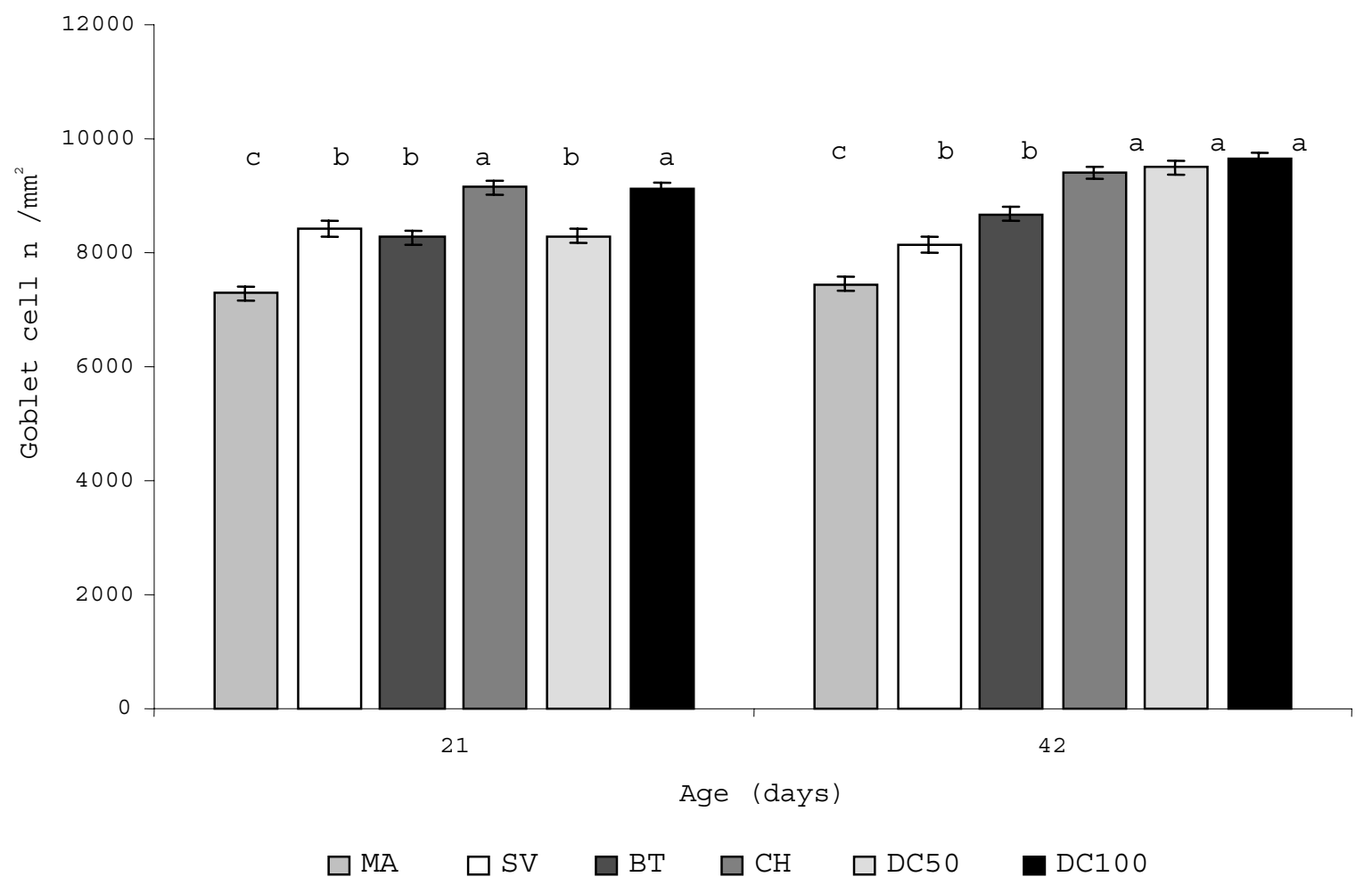

Figure 2 Effect of dietary sorghum tannin ingestion on goblet cell density in jejunum of broiler chicks at 21 and 42 days. Values are means \pm s.e.m., $n=4$ measurements. a, b or c - Bars with different letters above represent means that differ significantly $(\mathrm{P}<0.05)$

To determine whether PA diets influence intestinal integrity and disaccharide absorption, the rate of disaccharide hydrolysis was measured. Sucrase activity $(\mu \mathrm{g} / \mathrm{min} / \mathrm{mg}$ protein) tended to be lower $(\mathrm{P}<0.001)$ in the DC100, CH and BT groups in the first 21 days (Figure 3). Differences amongst treatments were eliminated at 42 and 56 days, even though DC100 tended to be lower in both regards. Maltase activity was unaffected by treatment throughout the trial. Changes in sucrase or maltase activity observed with different PA levels may represent changes in the quantity of enzyme present or alterations in the kinetic characteristics of the enzyme. Proanthocyanidins have the capacity to bind, coagulate and precipitate protein rendering the bound protein unavailable for digestive processes (Hagerman \& Butler, 1981) and by reducing enzymatic activity thus reducing the rate of protein digestion in the duodenum (Haslam, 1974; Hagerman and Butler, 1981). The reduction in sucrase activity was consequently unexpected since PAs encounter and bind to 
proteolytic enzymes first. However, Nguz et al. (1998) showed that the reaction though affecting the rate of enzyme activity, is not completely inhibitory, suggesting that PA could form multiple complexes along the digestive tract with some enzymes, in this case sucrase and not others.

(a)
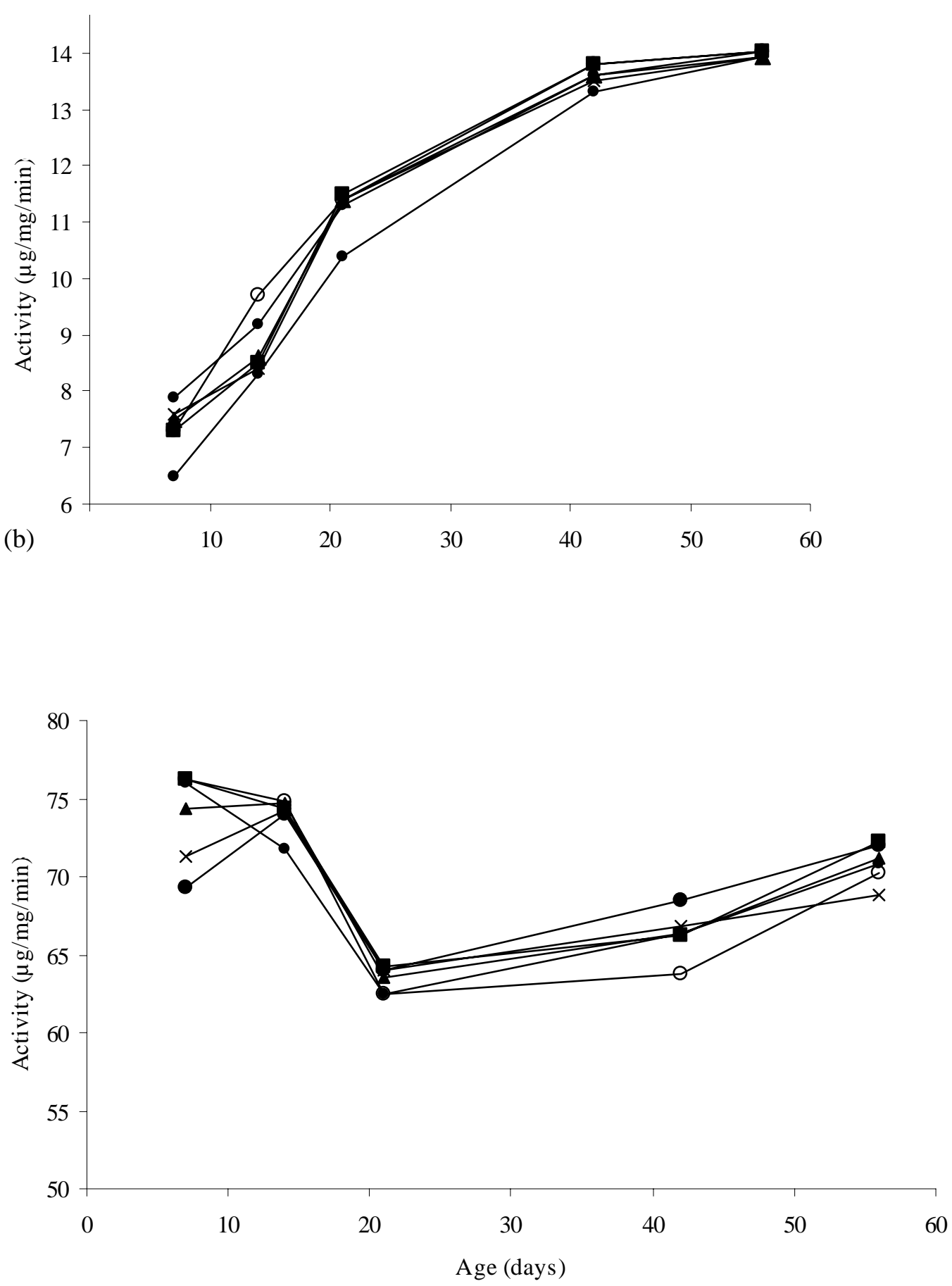

Figure 3 Activities of (a) sucrase and (b) maltase ( $\mu \mathrm{g} / \mathrm{min} / \mathrm{mg}$ protein) in the jejunum of broilers fed MA

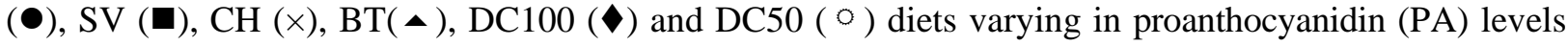
with age $(n=6)$ 
Motilva et al. (1983) studied the glucose absorption in the small intestine of rats in the presence of saline extracts of different legume seeds, (Phaseolus vulgaris and Vicia faba L.). They reported that there was an inverse relationship between the polyphenolic content of the extracts and the rate at which D-glucose was absorbed. The authors suggested that the polyphenols in the extracts might react with the brush border, thereby modifying proteins resulting in the impaired glucose transport without gross morphological changes. Butler et al. (1984) have suggested that the anti-nutritional effects observed in high PA sorghum may have been caused by non-tannin components that are linked to high PA expression in sorghum grains. However, the observations made in in vitro experiments by Nyamambi et al. (2000) using pure PA extracts showed the same reactivity trend as sorghum PA in the gut. The interactions between sorghum tannins and proteins involve both hydrogen binding and non-polar hydrophobic associations.

Correlation coefficients of villus height $(\mu \mathrm{m})$, crypt depth $(\mu \mathrm{m})$, sucrase and maltase activity $(\mu \mathrm{g} / \mathrm{mg} / \mathrm{min})$ and goblet cell number $\left(\mathrm{no} / \mathrm{mm}^{2}\right)$ at age $7,14,21,42$ and 56 days are shown in Table 4 . There were no significant associations between villus height, crypt depth, sucrase and maltase activities with respect to PA at 14, 21, 42 and 56 days. On day 7, villus height and crypt depth had a significantly $(\mathrm{P}<0.001)$ negative association with PA level. Generally, the lack of correlation between PA and morphological measurements suggests a lack of relationship between intestinal growth and performance, though the possibility of compounding physiological factors an in vivo experiment cannot be ruled out. Such factors may interact with polyphenols or mask the effects of polyphenols thus enhancing or protecting the animal from magnified effects seen in in vitro experiments or artificial levels of tannins introduced (Jansman, 1993). The range of lysine and methionine levels was formulated to meet and was within the recommended requirements for broilers (NRC, 1984).

There was a significant negative association between total liver lipid content, esterified cholesterol and triglycerides and PA level and type at 42 days. This demonstrates the ability of sorghum grain PA or its other phytochemical constituents to alter lipid and cholesterol when fed to chicks. Because this study was carried out with dietary PA levels contained in sorghum grain, it is difficult to attribute the association solely to the PA content. However, similar results were observed in rats fed up to $8 \mathrm{~g} / \mathrm{kg}$ of dietary flavonoids (quercetin ++ catechin) which are pure PA molecules (Fremont et al., 1998).

The liver sections of $\mathrm{CH}$ and DC100 fed birds showed mild bile duct hyperplasia and there were indications of fibrosis in sections of BT fed chicks. Granulomas were also prevalent in the DC100 samples. The observed lesions could not be fully attributed to dietary PA at all ages. However, livers of chicks fed sorghum diets were lighter red in colour than MA fed birds. The colour changes associated with feeding sorghum grain to chicks may infer a nutritional difference between sorghum and maize. The colour change was observed in both low and high PA sorghum diets. Liver colour is usually reddish-brown due to its excessive blood content. However, there are circumstances that may readily induce changes to occur, such as lipid accrual, which imparts a yellowish cast with increasing concentration of lipid (Moran, 1982). Consequently, the liver lipid content and cholesterol content were measured (Table 5). Liver lipids (g) were significantly reduced by dietary phenolics but liver triglycerides concentration ( $\mu \mathrm{mol} / \mathrm{g}$ wet weight) was significantly increased in broilers fed DC50 compared with other treatment groups.

Correlations of liver lipid with dietary PA content suggest an association between sorghum PA levels and liver lipid content. However grain sorghum is a rich source of other phytochemicals such as plant sterols and policosanols more likely to be associated with lipid content changes. These are thought to have the strongest influence on cholesterol metabolism as demonstrated in rats (Carr et al., 2005) and humans (Varady et al., 2003). Policosanols are long chain alcohols, typically 24-34 carbons in length that are quickly oxidised to long chain fatty acids. Phenolic compounds and PA have demonstrated a modest cholesterol lowering ability in some studies (Oliviera et al., 1994; Santos Buelga et al., 2000). The majority of studies, however, did not show a significant cholesterol lowering effect of phenolics compounds. Thus, additional studies should be carried out to investigate the contribution of sorghum phytochemical constituents to the lipid metabolism, lipid profiles of the liver, plasma and abdominal fat in broilers. 
Table 4 Correlation coefficients of proanthocyanidin (PA) level against villus height, crypt depth, sucrase and maltase activity at 7, 14, 21, 42 and 56 days

\begin{tabular}{llllll}
\hline & \multicolumn{5}{c}{ Day } \\
\cline { 2 - 6 } & 7 & 14 & 21 & 42 & 56 \\
\hline Villus height & $-0.89^{*}$ & -0.39 & -0.46 & -0.39 & -0.45 \\
Crypt & $-0.89^{*}$ & -0.39 & -0.46 & -0.39 & -0.45 \\
Sucrase & 0.29 & 0.29 & -0.17 & -0.04 & -0.05 \\
Maltase & -0.013 & -0.01 & -0.31 & -0.16 & -0.32 \\
Goblet cells & - & - & $0.75^{2}$ & $0.82^{*}$ & - \\
\hline $\mathrm{P}<0.001$ & & & & & \\
\hline
\end{tabular}

$* \mathrm{P}<0.001$

Table 5 Liver lipid composition of birds fed sorghum diets varying in PA level, measured at 42 days

\begin{tabular}{|c|c|c|c|c|c|c|c|c|c|}
\hline & \multicolumn{6}{|c|}{ Treatments $^{y}$} & \multirow{2}{*}{ m.s. $d^{x}$} & \multirow{2}{*}{$\mathrm{P}$ value } & \multirow{2}{*}{$\begin{array}{l}\text { Correlation } \\
\text { Day } 42\end{array}$} \\
\hline & MA & SV & $\mathrm{BT}$ & $\mathrm{CH}$ & DC50 & DC100 & & & \\
\hline Total lipid (g) & $4.53^{\mathrm{a}}$ & $4.27^{\mathrm{ab}}$ & $4.17^{\mathrm{ab}}$ & $3.45^{\mathrm{ab}}$ & $3.38^{\mathrm{b}}$ & $3.47^{\mathrm{ab}}$ & 1.15 & 0.167 & $-0.83 *$ \\
\hline Phospholipids ( $\mu \mathrm{mol} / \mathrm{g})$ & $16.0^{\mathrm{c}}$ & $16.7^{\mathrm{a}}$ & $16.2^{\mathrm{bc}}$ & $16.2^{\mathrm{bc}}$ & $16.5^{\mathrm{ab}}$ & $15.9^{\mathrm{c}}$ & 0.35 & 0.003 & -0.60 \\
\hline Free cholesterol ( $\mu \mathrm{mol} / \mathrm{g})$ & $3.81^{\mathrm{a}}$ & $3.57^{\mathrm{ab}}$ & $3.41^{\mathrm{b}}$ & $3.43^{\mathrm{ab}}$ & $3.87^{\mathrm{ab}}$ & $3.40^{\mathrm{ab}}$ & 0.38 & 0.151 & -0.28 \\
\hline Esterified cholesterol ( $\mu \mathrm{mol} / \mathrm{g})$ & $11.44^{\mathrm{a}}$ & $9.32^{\mathrm{b}}$ & $8.52^{c}$ & $4.54^{\mathrm{d}}$ & $4.35^{\mathrm{d}}$ & $4.20^{\mathrm{d}}$ & 0.34 & $<0.001$ & $-0.90^{*}$ \\
\hline Triglyceride $(\mu \mathrm{mol} / \mathrm{g})$ & $3.19^{c}$ & $3.44^{\mathrm{c}}$ & $2.68^{\mathrm{c}}$ & $5.39^{\mathrm{b}}$ & $5.31^{\mathrm{b}}$ & $6.80^{\mathrm{a}}$ & 0.30 & $<0.001$ & $-0.97 *$ \\
\hline PA (A550nm/g DM) & 0 & 0.07 & 0.20 & 1.68 & 2.48 & 2.48 & & & \\
\hline
\end{tabular}

${ }^{x}$ m.s.d. - mean square difference.

${ }^{y}$ Treatments - MA = Maize; SV = SV2; BT = Brown Tsweta CH= Chirimaugute DC50 = 50/50 w/w maize/DC75; DC100 = $100 \mathrm{w} / \mathrm{w}$ DC75

a bcd Row means with different superscripts differ significantly $(\mathrm{P}<0.05)$

PA - proanthocyanidins

${ }^{z}$ Correlation coefficients of PA level against liver lipid with PA measured at day $42(* \mathrm{P}<0.001)$ 
It has also been argued that sorghum PAs are not directly absorbed into the systemic circulation due to the size of the molecules or membrane barriers (Ortiz et al., 1994). However, studies with radioactively labelled sorghum PA fed to chicks showed significant levels of the label in the serum, liver and kidneys (Butler et al., 1986). In a study using ${ }^{14} \mathrm{C}$ labelled sorghum condensed tannins, analyses of the ${ }^{14} \mathrm{C}$ distribution in tissue and excreta samples indicated that the condensed tannins were not absorbed from the gastrointestinal tract but lower molecular weight phenolics were absorbed suggesting that they would have an effect on the liver morphology (Jimenez-Ramsey et al., 1994).

\section{Conclusion}

The study examined the effect of feeding dietary sorghum PA on intestinal growth and function of broiler chicks. The high PA sorghum diets caused histological lesions in varying degrees in the small intestine of chicks but not growth depression. We concluded that the small changes in villus height and sucrase activity suggest that digestive hypertrophy is not a major effect of the dietary tannin levels fed. This may reflect insufficient challenge to the intestinal morphology and its function from feeding dietary PA levels as those fed in this experiment. The effects of dietary PA on body growth may therefore be due more to biochemical events occurring in other parts of the gastrointestinal tract such as enzyme inhibition and events outside of the gastrointestinal tract. The liver lipid content suggests post absorptive effects that are induced by tannin effects in the intestine and these should be examined further.

\section{References}

Ahmed, A.E., Smithard, R. \& Ellis, M., 1991. Activities of enzymes of the pancreas and lumen and mucosa of the small intestine of growing broiler cockerels fed on tannin-containing diets. Br. J. Nutr. 65, 189-197.

AOAC. 1990. Association of Official Analytical Chemists. Association of Official Analytical Chemists Handbook of Official Analytical Methods Washington D.C., USA.

Armstrong, W.D., Featherston, W.R. \& Rogler, J.C., 1974. Effects of bird-resistant sorghum grain and various commercial tannins on chick performance. Poult. Sci. 53, 2137-2142.

Beart, J.E., Lilley, T.H. \& Haslam, E., 1985. Plant polyphenols- secondary metabolism and chemical defence - some observations. Phytochem. 24 (1), 33-38.

Butler, L.G., 1992, Anti-nutritional effects of condensed tannins and hydrolysable tannins. In: Plant Polyphenols. Eds. Hemingway, R.W. \& Labs, P.E., Plenum Press, New York. pp. 693-698.

Butler, L.G., Riedl, D.J., Lebryk, D.G. \& Blytt, H.J., 1984. Interactions of proteins with sorghum tannin: Mechanism, specificity and significance. J. Am. Oil Chem. Soc. 61, 916-920.

Butler, L.G., Rogler, J.C., Mehansho, H. \& Carlson, D.M., 1986. Dietary effects of tannins. In: Plant Flavonoids in Biology and Medicine: Biochemical, Pharmacological and Structure-Activity Relationships. Ed. Cody, V., New York.

Carr, T.P., Andresen, C.J. \& Rudel, L.L., 1993. Enzymatic determination of triglyceride free cholesterol and total cholesterol in tissue lipid extracts. Clin. Biochem. 26. 39-42.

Carr, T.P., Weller, C.L., Schlegel, V.L., Cuppett, S.L., Guderain, D.M. \& Johnson, K.R., 2005. Grain sorghum lipid extracts reduces cholesterol absorption and plasma non-HDL cholesterol concentration in hamsters. J. Nutr. 135, 2236-2240.

Dahlqvist, A., 1964. Method for assay for intestinal disaccharidases. Anal. Biochem. 22, 99-107.

Douglas, J.H., Bond, P.L., Sullivan, T.W. \& Struwe, F.J., 1990. Nutrient composition and metabolisable energy value of selected sorghum grain varieties and yellow corn in broiler diets. Poult. Sci. 69, 1147-1155.

Elkin, R.G., Rogler, J.C. \& Sullivan, T.W., 1990. Comparative effects of tannins in ducks, chicks and rats. Poult. Sci. 69, 1685-1693.

Fremont, L., Gozellino, M.T., Franchi, M.P. \& Linaird, A., 1998. Dietary flavonoids reduce lipid peroxidation in rats fed polyunsaturated or monosaturated fat diets. J. Nutr. 128, 1495-1502.

Farrell, D.J., Perez-Maldonado, R.A. \& Brooker, J.D., 1999. Tannins in feedstuffs used in the diets of pigs and poultry in Australia in Tannins in Livestock and Human Nutrition, Proceedings of an International Workshop, Adelaide, Australia, 31 May - 2 June. pp. 24-29.

Folch, J., Lees, M. \& Sloane-Stanley, G.H., 1957. A simple method for the isolation and purification of total lipids for animal tissues. J. Biol. Chem. 224, 497-509. 
Hagerman, A.E. \& Butler, L.G., 1981. Specificity of proanthocyanidin-protein interactions. J. Biol. Chem. 256, 4494.

Haslam, E., 1974. Polyphenol-Protein interactions. Biochem. J. 139, 285-288.

Jimenez-Ramsey, L., Rogler, J.C., Housley, T.L., Butler, L.G. \& Elkin, R.G., 1994. Absorption and distribution of ${ }^{14} \mathrm{C}$-labelled condensed tannin and related sorghum phenolics in chickens. J. Agric. Food Chem. 42, 963-967.

Langhout, D.J., Schutte, J.B., Van Leeuwsen, P.V., Weinberger, J. \& Tamminga, S., 1999. Effect of dietary high and low methylated citrus pectin on the activity of the ileal microflora and morphology of the small intestine wall of broiler chicks. Br. Poult. Sci. 40, 340-347.

Lowry, O.H., Rosebrough, N.J., Farr, A.L. \& Randall, R.J., 1951. Protein measurement with Folin phenol reagent. J. Biol. Chem. 193, 265-273.

Mitjavila, S., Lacombe, C., Carrera, G. \& Derache, R., 1977. Tannic acid and oxidised tannic acid on the functional state of rat epithelium. J. Nutr. 107, 2113-2121.

Moran Jr., E.T., 1982. Comparative Nutrition of Fowl and Swine: The Gastrointestinal Systems, Ontario Canada. pp. 120-124.

Motilva, M.J., Martinez, J.A., Ilundani, A. \& Larraulde, J., 1983. Effects of extracts of faba bean (Ph. vulgaris) and field bean (Vicia faba) varieties on mucous secretion. J. Sci. Food Agric. 34, 239-246.

Nguz, K., Van Gaver, D. \& Huyghebaert, A., 1998. In vitro inhibition of digestive enzymes if sorghum condensed tannins (Sorghum bicolour L. Moench). Sci. de Aliments. 18, 507-514.

Noy, Y., Geyra, A. \& Sklan, D., 2001. The effect of early feeding on growth and small intestinal development in the posthatch poult. Poult. Sci. 80, 912-919.

Nyachoti, C.M., Atkinson, J.L. \& Leeson, S., 1996. Response of broiler chicks fed a high tannin sorghum diets. J. Appl. Poult. Res. 5, 239-245.

Nyamambi, B., Ndlovu, L.R., Read, J.S. \& Reed, J.D., 2000. The effects of sorghum proanthocyanidins on digestive enzyme activity in vitro and in the digestive tract of chicken. J. Sci. Food Agric. 80, 2223-2231.

Oliviera, P.B., Murakami, A.E. \& Garcia, E.R., 2000. Influence of antinutritional factors of leucaena (Leucaena leucocephala and Leucaena cunningan) and pigeon pea (Cajanus cajan) on the intestinal epithelium and performance of broiler chickens. Rev. Bras. Zootec. Nov/Dec 29 (6), 1759-1769.

Ortiz, L.T., Alzuetta, C., Trevino, J. \& Castano, M., 1994. Effects of faba bean tannins on the growth and histological structure of the intestinal tract of chicks and rats. Br. J. Nutr. 35, 743-754.

Porter, L.J., Hrstich, L.N. \& Chan, B.G., 1986. The conversion of procyanidin and prodelphinidins to cyanidins and delphinidin. Phytochem. 25, 223-230.

Rubio, L.A., Brenes, A. \& Castano, M., 1990. The utilisation of raw and autoclaved faba beans; Vicia faba L (var. minor) and faba bean fractions in diets for growing broiler chicks. Br. J. Nutr. 63, 419-430.

Santos-Buelga, G. \& Scalbert, A., 2000. Proanthocyanidins and tannin-like compounds. Nature occurrence, dietary intake and effects on nutrition and health. J. Sci. Food Agric. 80, 1097-1117.

SAS, 2000. Statistical Analysis System user’s guide. Version 6. SAS Institute. Cary. N.C., USA.

Sell, D.R., Reed, W.M., Chrisman, C.L. \& Rogler, J.C., 1985. Mucin excretion and morphology of the intestinal tract as influenced by sorghum tannins. Nutr. Rep. Int. 31, 1369-1374.

Smirnov, A., Sklan, D. \& Zehava, U., 2004. Mucin dynamics in the chick small intestines are altered by starvation. J. Nutr. 134, 736-742.

Uni, Z., Ganot, S. \& Sklan, D., 1998. Posthatch development of mucosal function in the broiler small intestine. Poult. Sci. 77, 75-82.

Varady, K.A., Wang, Y. \& Jones, P.J.H., 2003. Role of policosanols in prevention and treatment of cardiovascular disease. Nutr. Rev. 61, 376-383.

Welsch, C.A., Lachance, P.A. \& Wasserman, B.P., 1989. Effects of native and oxidised phenolic compounds on sucrase activity in rat BBM vesicles. J. Nutr. 119, 17371740. 